\title{
PROBLEMS OF PROVIDING PUBLICK SERVICES: COMPERATIVE LEGAL ANALYSIS
}

\author{
Gulnara Useinova $^{1 *}$, Dzhambulat Saidumov ${ }^{2}$, Duman Kusainov ${ }^{1}$, Nurlybek Tauekelov ${ }^{1}$, \\ Marat Saidumov ${ }^{2}$ \\ ${ }^{1}$ Al-Farabi KazNU, pr. al Farabi, 71, 050040 Almaty, Republic of Kazakhstan \\ ${ }^{2}$ Chechen State University, A. Sharipova st., 32, 364907, Groznyi, Russia
}

\begin{abstract}
Abstact. The relevance of this article is due to several factors. These include: acceleration of digital modernization processes in Kazakhstan under the influence of global informatization leads to the transition to electronic document management; improving the efficiency of the Kazakh government through the introduction of information technology; the need to develop a state policy in the field of the application of new technologies in all spheres of life (NAO "State Corporation" Government for Citizens "); the need to accelerate the economic and political modernization of Kazakhstani society through the widespread use of information technology, as well as theoretical and practical interest in exploring the potential benefits of e-government and electronic document management.

The essence of the new stage of the administrative reform in Kazakhstan is reduced to a short formula - from administration to management. Demanding the efficiency and quality of the provision of public services should become the central point of government service policy.

Key words: public service, electronic government, state administration, rights and obligations of citizens, government bodies.
\end{abstract}

\section{Introduction}

The relevance of the topic of this article is due to the fact that open and equal access to highquality public services for everyone is one of the main tasks of any state in the modern period. The competent provision of public services means providing conditions for a decent life for their citizens.

The process of providing public services covers all areas and the period of a person's entire life. From birth, a person begins to interact with the state. Interaction is carried out by obtaining public services. Thus, the very first public service from the moment of birth for each citizen is to obtain a birth certificate, then receive special social benefits, etc. We can say that a citizen is completely dependent on the activities of the state, and the state, in turn, must provide him with the necessary conditions for a full life.

It is no secret that the state's activity in providing public services in the post-Soviet countries, including Kazakhstan, is at the stage of formation.

\footnotetext{
*Correspondingauthor: gulnara_usein@mail.ru
} 
The state's activity in providing services is ahead of both scientific research and its legal regulation. This necessitates extensive scientific research.

\section{Methods}

The methodology of the presented research is based on the combination of the general scientific and private scientific requirements.

The general scientific methodology characterizes the approach to the correlation of the state, society and personality. It includes taking into account objective and subjective factors of social development, cause and effect relationships and relationships, their institutionalization and subordination.

The topic of the scientific article is revealed using such General scientific methods of cognition as: dialectical, historical, logical, analysis, synthesis, induction and deduction; private scientific methods-technical - legal, comparative-legal.

Thus, on the basis of a comparative legal analysis of the state of availability and quality of public services in the Republic of Kazakhstan and foreign countries, theoretical provisions are formulated on the need to improve the efficiency of this process by ensuring equal access to public services and improving their quality.

\section{Discussion}

Availability of a public service is a characteristic of the service delivery process. It determines whether applicants can receive the service, taking into account all objective restrictions. These characteristics are General (apply to all categories of applicants) and specific (apply to individual categories of applicants, for example, for people with disabilities). When receiving public services, the applicant must rely on courtesy and efficiency in service, on the completeness, reliability and relevance of information about the procedure for providing services [1]. Unfortunately, the principle of accessibility of requests for state and municipal services cannot include in its meaning the full quality of service to citizens. After all, providing unhindered access to places where services are provided does not mean guaranteeing high quality of the service process and consideration of citizens ' claims (complaints) to service providers [2].

To ensure equal access to public services, it is necessary to overcome: first, infrastructure inequality, and second, information inequality.

The state should ensure the development of telecommunications infrastructure and thus create conditions for equal access to public services in electronic form, both for residents of the metropolis and remote territories.

It should be noted that, as a rule, there are no problems with the Internet in large cities, but in remote areas the level of penetration of ICT and other communication services is not high enough.

This can be explained by the fact that it is often economically unprofitable for commercial structures to create telecommunications networks in small remote areas, towns, and villages. In our view, it is impossible to overcome infrastructure inequality at one time. However, in order to overcome the infrastructure inequality, it is necessary that Internet connection is mandatory in remote areas.

Currently, $72 \%$ of citizens of Kazakhstan have access to the Internet (see Table 1).

It should be noted that in general, to provide the 18-millionth population of our republic with a broadband Internet is planned by 2022 . 
Table 1 - Share of Internet users in percent (\%) [3].

\begin{tabular}{|l|c|c|c|c|c|c|c|}
\hline index & 2011 & 2012 & 2013 & 2014 & 2015 & 2016 & 2017 \\
\hline Internetusersaged 6-74 & 50,6 & 61,9 & 63,3 & 63,9 & 72,9 & 76,8 & 78,8 \\
\hline $\begin{array}{l}\text { Internet users at the age of 6- } \\
15 \text { years ** }\end{array}$ & 55,8 & 32,0 & 42,5 & 43,6 & 53,1 & 62,1 & 67,9 \\
\hline Internetusersaged 16-74 & 49,5 & 67,9 & 67,6 & 68,1 & 77,2 & 80,2 & 81,5 \\
\hline
\end{tabular}

Source: Committee on Statistics of the Republic of Kazakhstan

Until recently, the work on Informatization was carried out by almost everyone, but it was scattered and not clear to everyone. The creation of a unified information system that is understandable to both those who provide services and those who receive them has made it possible to take a step towards increasing the availability of public services and, ultimately, the quality of people's lives.

According to Tolmachev V. A., there are four main conditions for the real availability of public services: territorial, financial, intuitive and conceptual, and prohibiting overformalism [3].

Then it reveals each of the conditions. Thus, territorial accessibility is understood as the ability of theapplicant to reach the place of providing or applying for the provision of public services with the least time costs. Such accessibility should include" step-by-step " accessibility or easy access by public transport. Financial accessibility - the ability of the applicant to obtain the result of providing public services with the lowest financial costs. This economic component, according to the author, should be focused on socially vulnerable segments of the population. In practical terms, financial affordability may be manifested in the establishment of benefits in terms of fees for certain categories of applicants. Regarding intuitive and conceptual accessibility, the author notes that it should be understood as " the ability to get the result of providing public services "for life situations" [3].

Under the prohibition of over-formalism, the author understands the applicant's ability to apply for the provision of public services and get the result without obstacles and excessive formalism and bureaucracy.

At the international level, the problem of information inequality was first raised in the Okinawan Charter of the global information society, signed by the leaders of the G8 countries in the summer of 2000 [4].

In accordance with this Charter, the international expert Council of the Digital Opportunity Task Force (G8 DOT Force) was created, which developed an action plan that was presented to the leaders of the G8 countries at a meeting in Genoa in the summer of 2001. NAO State Corporation "Government for Citizens" carries out its activities in accordance with the Strategic Plan for 2016 - 2020.

The Genoese action plan consists of the following items: to assist developing countries in developing and implementing national ICT strategies; to ensure improved connectivity of networks, development of accessibility and reduction of the cost of access; to develop human resources, the volume and accessibility of knowledge; to encourage entrepreneurship in order to ensure economic development; to develop a common international policy in the field of information and communication technologies to involve all countries and segments of society; ensure the development and maintenance of targeted programs for the inclusion of least developed countries in the global information society; use ICT capabilities in the fight against AIDS and other infectious diseases; ensure the creation of local information resources 
and applications; and establish ICT as a priority for multilateral initiatives in the G8 and other international organizations and programs.

GenoeseActionPlan

assist developing countries in developing and implementing national ICT strategies take advantage of ICT in the fight against AIDS and other infectious diseases

ensure the development and maintenance of targeted programs for the inclusion of least developed countries in the global information society
Provide improved network connectivity, improved accessibility and reduced access costs

in order to ensure economic development stimulate entrepreneurship

ensure the creation of local information resources and applications

in order to develop a common international policy in the field of information and communication technologies, to attract all countries and sectors of society

establish ICT as a priority for multilateral initiatives in the G8 and other international organizations and programs.

Fig. 1 - Genoese action plan.

It should be noted that many of these recommendations have already led to concrete actions and projects, mainly in Africa and other developing regions.

In the Republic of Kazakhstan, equal access to public services is provided By the state Corporation "Government for citizens". This Corporation was created as part of the implementation of step 100 "national Plan-100 concrete steps".

NAO State Corporation "Government for citizens" carries out its activities in accordance with the Strategic plan for 2016 - 2020, which consists of 6 sections.

The mission of the NAO is to improve the quality, transparency and accessibility of public services provided to individuals and legal entities by a single provider of public services.

The State Corporation does a lot of work with people with disabilities. So, when opening front offices, taking into account the interests of people with disabilities, all of them were equipped with ramps, call buttons, tactile signs in Braille. Private Parking spaces are 
provided in Parking lots for the disabled. In addition, disabled people of group I and II can receive public services at home by making a free call to 1414 and submitting an application.

In March 2018, "the Surdo-online project for hearing impaired citizens was launched in a pilot mode, through which a qualified sign language specialist provides sign language translation in real time from a special duplicate monitor" [6].

As part of the Digital Kazakhstan program, it is planned to expand the number of public services provided proactively. The "proactive" approach allows the state to forecast demographic, agricultural, and industrial processes based on the collection of information and its effective processing. "Proactive" disclosure of information provides a certain method of informing. State bodies publish information on their own initiative. This information is of public importance. It is assumed that in various life situations, the state itself will offer a citizen to get a specific service. For example, enrolling in a school, assigning payments for social risks, registering real estate, and so on.

In order to achieve sustainable results in public services, it is necessary to simultaneously develop appropriate infrastructure elements to support the public service delivery system. "Such infrastructure implies the creation of a network of organizations and institutions that facilitate the process of providing public services through research, creating information databases, providing advice and training for both civil servants and consumers of services" [7, p. 77]. The principles of implementing the activities of such organizations abroad include the following: maximum proximity and focus on the needs of the consumer; professionalism in managing activities and providing services; sustainability of results; practical benefits from their activities.

For example, in Canada, there are telephone centers "1-800 Canada". These centers provide citizens with the necessary information about where and when to get a certain service. Functioning "access Centers" provide consulting services for beginning entrepreneurs. These centers are located in government buildings throughout Canada. Their peculiarity is that in addition to providing advice to entrepreneurs, they provide a significant number of public services and work on the principle of "one window".

In Poland, a public service Information center was established in 2002. The purpose of the creation is to expand access of ordinary citizens and civil servants themselves to information about the types of public services, areas of activity of individual state bodies and institutions, etc.

As part of the reform of the administrative system in Greece, a "quality Program "has been developed. The program provides for the creation of Advisory centers for the provision of public services, United in a single information network.

A pilot project was implemented in one of the regions of Hungary, in which an information center was established with the participation of all state institutions.

This center gave citizens access to information about interaction with various government services. In the future, this experience was distributed throughout the country [8, p. 15].

The use of new information and communication technologies will increase consumers ' access to public services and information about them.

In Australia, the Commonwealth service agencies act was passed in 1997. The Centrelink state institution was created on the basis of this law. It provides public services on behalf of and in partnership with 25 Federal ministries and government agencies via the world wide web, telephone customer service centers, and in regular offices [7, p. 16].

In Germany, the e - government program "Bund Online-2005"has been developed. The provision of services by administrative bodies of the state is improved by using new information technologies. The Federal government already provides 170 types of services using the Internet. Special attention is paid to the simplification of registration procedures for small and medium-sized businesses [9]. 
A characteristic feature of the reform of the public service delivery system in the countries under review is the duration of this process. For example, the "Charter of services" system, initiated in the UK in 1991, was designed for 10 years, but the improvement of individual components of this system is still ongoing.

The "first priority - customers" program, adopted in the United States in 1993, also continues to this day.

Since the early 1980s, Malaysia has initiated reforms in public services. Reforms in this area continue at the present stage of the state's development, and measures taken in this area are included in the 5-year development plans and the strategic plan "Prospect-2020" [7].

The essence of the new stage of administrative reform in Kazakhstan is reduced to a short formula - from administration to management.

The development of e-government is a guarantee of the availability of public services.

The concept of "e-government" has long had a global status. The first mention of this term dates back to 1991 .

"E-government" is one of the most complex social and legal phenomena that can be studied both from a political, economic, organizational, and legal point of view.

From a legal point of view, "e-government" is actually a set of administrative and legal institutions with a specific content and structure. Of particular interest is the study of its legal nature, as well as the preparation of proposals for improving its activities.

Currently, the legal science has not formed a single systematic approach to such a phenomenon as"e-government". Inshakova E. G. notes that "the main reason is the fact that the definitions of" e-government "are formulated according to different principles" [9, p. 22]. And you can't disagree with that. All research authors can be divided into two groups. The first group of authors, based on the ongoing transformations, both in the society itself and in its individual structural elements, prefer to give descriptive definitions of the concept of "egovernment. The second group of authors, defining the concept of "e-government", is guided only by the practical side.

According to the definition of Bachilo I. L., "e-government" is a system of bodies and organizations aimed at creating conditions under which the formation of such parameters of the Russian state is ensured, under which it can be considered as an information society" [10, p. 220]. Korotkov A.V. the following characteristic of "e-government" is proposed: it is public administration using information and communication technologies to provide public services, improve relations with citizens and organizations, between public authorities, as well as internal procedures of activity" [11, p. 250].

A number of authors Express the view that the essence of "e-government" is to optimize administrative procedures at the state, regional and municipal levels. In this area, it is proposed to include with full confidence all aspects related to the use of information highways in public activities [13, p. 118].

Kashina E. A. believes that e-government is a new form of relationship between the state and society, characterized by expanding the volume and improving the quality of services provided by the state to businesses and citizens in the virtual space, reducing management costs, reducing transaction costs, giving impetus to the development of the "new economy", democratization of society, and strengthening the effectiveness of the fight against corruption [14].

According to Yakovleva E. A., "E-government" means a new way of organizing and developing the system of public administration, a way of transforming and improving it in order to focus on a fundamentally closer relationship with citizens, radically improving the indicators of obtaining specific useful results of activity, and increasing the efficiency and responsibility of state bodies." The researcher notes that "there are two main models of political strategy for the formation of e-government: "Western" and "Eastern". The process of reforming public administration in Western countries, based on the model of electronic 
democracy, is inextricably linked to the reorganization of state bodies based on the principles of "new public administration". E-government implementation projects in Eastern countries are successfully implemented on the basis of applying the principles of "rational bureaucracy" [15].

According to G. R. Useinova, D. Yu.n., there are four models of "e-government" formation. These are continental-European (Germany, France, etc.), Anglo-American (USA), Asian (South Korea, Singapore, Japan, etc.) and Russian models [16, p. 10]. Each model of e-government formation has its own characteristics and characteristics, as well as a classification, and weconsider it insufficient to divide them only into Western and Eastern ones at the present time.

According to the author, Kazakhstan, as well as Russia, is characterized by a systematic and gradual transition to the introduction of the idea of e-government. The author identifies four stages in Kazakhstan and five stages in Russia.

A key factor in the formation of a sustainable e-government is, of course, cyber securityas the state of security of electronic information resources provided by the implementation of measures to protect systems, networks and software applications from digital attacks.

"The most common obstacles to the formation of a sustainable e-government are insufficient training and accessibility, as well as digital illiteracy" [16, p. 25]. In order to overcome such obstacles in the field of cyber security, it is necessary to implement the following set of measures: improving national and international legislation in the field of cyber security; creating favorable conditions for investment in cyber security; development of modern technologies and integration of appropriate technical capabilities to detect and respond to cyber attacks and to ensure an atmosphere of trust and security; establishment of minimum security criteria and certification schemes for software applications and systems; strengthening of mutual cooperation between authorities, organizations, enterprises, etc.

Many countries have adopted State programs to protect cyberspace: the US national cyber strategy for 2018; the UK national cyber security strategy for 2016-2021; the Estonian cyber security Strategy for 2008-2013; the German cyber security Strategy for 2011, and others.

The Government of the Republic of Kazakhstan approved the concept of cyber security ("cyber Shield of Kazakhstan") on June 30, 2017.

(See Figure 2)

observance of the rights, freedoms and legitimate interests of individuals, as well as the rights and legitimate interests of legal entities continuous monitoring of information security of information and communication infrastructure facilities

ensuring the safety of individuals, society and the state in the application of information and communication technologies

the implementation of activities on informatization in the Republic of Kazakhstan on the basis of common standards that ensure the reliability and controllability of informatization facilities integration of the national security system with international security systems.

clear delineation of powers of state bodies

Fig. 2 - Principles for constructing the Concept of cyber security (“Cyber shield of Kazakhstan”). 
The concept is based on the following basic principles: respect for the rights, freedoms and legitimate interests of individuals, as well as the rights and legitimate interests of legal entities; ensuring the security of the individual, society and the state when using information and communication technologies;implementation of information activities on the territory of the Republic of Kazakhstan on the basis of uniform standards that ensure the reliability and manageability of information objects; clear separation of powers of state bodies; continuous monitoring of information security of information and communication infrastructure objects; integration of the national security system with international security systems.

The Concept seeks to achieve and maintain the level of security of electronic information resources, information systems and ICT infrastructure from external and internal threats to the sustainable development of the Republic of Kazakhstan in conditions of global competition.

It should be noted that the level of e-government development is reflected in the development index (IRE). This indicator shows that the world is making progress in developing sustainable e-government and providing public e-services.

However, digital barriers and differences in the level of e-government development continue to persist in some countries.

According to the UN data published in the global report, fourteen countries in the group with low IRE belong to the African least developed countries [17, p. 25].

According to the UN data, Denmark, Australia, and South Korea occupy the leading position in the world in providing public e-services. Behind them, the top ten includes the United Kingdom, Sweden, Finland, Singapore, New Zealand, France and Japan.

Thus, a high level of public e-services is typical for European and Asian States, as well as individual States of North and South America.

\section{Conclusion}

To ensure equal access to public services, it is necessary to overcome: first, infrastructure inequality, and second, information inequality.

The state should ensure the development of telecommunications infrastructure and thus create conditions for equal access to public services in electronic form, both for residents of the metropolis and remote territories.

Qualitative changes in the field of building "e-government "are impossible without fixing strict requirements based on the basic tasks of" e-government", one of which must necessarily be to increase the level of satisfaction of people with the quality of services provided.

The implementation of any service in electronic form does not mean the successful solution of the tasks of "e-government". Moreover, poorly implemented e-government services not only do not reduce time and resource costs on the part of Executive authorities, as well as recipients of the service, but also minimize the level of interest and trust of citizens in the "e-government", thereby inhibiting their perception, understanding and evaluation of other services.

Due to the fact that in separate literature and in law enforcement practice, the concepts of "quality of public service" and "quality of public service" are often identified, we consider it necessary to distinguish these concepts. Thus, the quality of public services should be understood as the degree of realization of the rights and freedoms of citizens provided by the Constitution and other legislative acts. The quality of service when providing a public service is primarily characterized by the openness of information about the service, the territorial accessibility of the place where it is received, the minimum waiting time for the applicant, and the comfort of conditions in the process of providing it. 
The most successful experience in implementing the e-government initiative is now recognized in the United States.

It is no secret that the ability to achieve sustainable development of e-government and improve the well-being of citizens is provided by rapidly developing technologies, since they can transform traditional ways of doing business within all the functions and spheres of the state.

However, this may also be a problem, since governments, due to objective and subjective factors, are often unable to respond quickly to the emergence of new technologies and use them to their advantage.

Summing up,it should be noted that in the process of building an "e-government", strict requirements must be fixed. One of the requirements is to increase the level of people's satisfaction with the quality of services provided.

However, the implementation of any service in electronic form does not yet mean the successful solution of the tasks of "e-government". Poorly implemented electronic public service reduces time and resource costs on the part of public authorities, as well as recipients of the service. It minimizes the level of interest and trust of citizens in the "e-government", thereby inhibiting their perception, understanding and evaluation of other services.

\section{References}

1. Tkachenko A. N., Nazarevskaya N. A. Providing public services / / Young scientist. 36, 72-76, 2017

2. Kiseleva N. Principles of providing state and municipal services / / State power and local self-government, 5, 21-25, 2014

3. Tolmachev V. A. the Concept of accessibility of state and municipal services / / Law and state: theory and practice. 8, 22-27, 2013

4. Okinawa Charter for the global information society. [Electronic resource]. - URL: http://www.iis.ru/library/okinawa/charter.ru.html. accessed 23.09.2019

5. "Government for citizens" ensures equal access to public services. [Electronic resource].

URL: $\quad$ https://gov4c.kz/ru/novosti/2018/04/12/pravitelstvo-dlia-grazhdanobespechivaet-ravnyi-dostup-k-gosuslugam. accessed 24.08.2019

6. Useinova G. R., Alaukhanov E. O., Ospanova D. A., Useinova K. R. Science and life of Kazakhstan. 5/2, 2019

7. Magerova A. B., Maksimov S. S., Scientific monograph. - Astana: Academy of public administration under the President of Kazakhstan, 2015

8. International Public Administration Reform: Implications for Russian Federation. / Nick Manning and Neil Parison, World Bank. - February, 2003

9. Inshakova E. G. "E-government" in public administration: administrative and legal problems of organization and functioning: Diss ... PhD - Voronezh, 2015

10. Bachilo I. L. State and law of the XXI century. Real and virtual. - Moscow: legal publishing house "YURKOMPANIE", 250-252, 2012

11. Korotkov A.V. State policy of the Russian Federation in the field of information society development. - Moscow: "TRAIN", 215-216, 2007

12. Dashyan M. S. Law of information highways: issues of legal regulation in the Internet sphere. - Moscow: VoltersKluver, 118-120, 2007

13. Kashina E. A. Formation of e-government in the Russian Federation: socio-political aspect: Diss ... Ph. D.-M., 2009

14. Yakovleva E. A. E-government: theoretical models and political strategy of the Russian state: Diss.. Ph. D.-M., 2006

15. Useinova G. R. International legal experience of formation and development of egovernment/ / Science and life of Kazakhstan, 3, 9-14, 2018 
16. UN Study: e-government. - New York, 2018 